\title{
Article \\ Prolonged Exposure to Oxaliplatin during HIPEC Improves Effectiveness in a Preclinical Micrometastasis Model
}

\author{
Nick Seyfried 1,2,3 ${ }^{D}$, Can Yurttas 1,*(D), Markus Burkard ${ }^{4}$, Benedikt Oswald ${ }^{2}$, Alexander Tolios 5,6,7 (D), \\ Franziska Herster ${ }^{2,8}$, Joseph Kauer ${ }^{2,9,10,11}$ (D), Tarkan Jäger ${ }^{12}{ }^{D}$, Ingmar Königsrainer ${ }^{1,13}$, Karolin Thiel ${ }^{1}$, \\ Markus Quante 1(D), Hans-Georg Rammensee 2,9,14 (D), Sascha Venturelli 4,15, Matthias Schwab 9,14,16,17,18, \\ Alfred Königsrainer 1,9,14, Stefan Beckert ${ }^{1,19}$ and Markus W. Löffler 1,2,9,14,16
}

Citation: Seyfried, N.; Yurttas, C.; Burkard, M.; Oswald, B.; Tolios, A.;

Herster, F.; Kauer, J.; Jäger, T.;

Königsrainer, I.; Thiel, K.; et al. Prolonged Exposure to Oxaliplatin during HIPEC Improves

Effectiveness in a Preclinical

Micrometastasis Model. Cancers 2022,

14, 1158. https://doi.org/10.3390/

cancers 14051158

Academic Editors: Sebastian Schölch, Christian Pilarsky and Georg Flügen

Received: 31 December 2021

Accepted: 12 February 2022

Published: 24 February 2022

Publisher's Note: MDPI stays neutral with regard to jurisdictional claims in published maps and institutional affiliations.

Copyright: (C) 2022 by the authors. Licensee MDPI, Basel, Switzerland. This article is an open access article distributed under the terms and conditions of the Creative Commons Attribution (CC BY) license (https:// creativecommons.org/licenses/by/ $4.0 /)$.
1 Department of General, Visceral and Transplant Surgery, University Hospital Tübingen, Hoppe-Seyler-Str. 3, 72076 Tübingen, Germany; nick.seyfried@tum.de (N.S.); ingmar.koenigsrainer@lkhf.at (I.K.); karolin.thiel@med.uni-tuebingen.de (K.T.); markus.quante@med.uni-tuebingen.de (M.Q.); alfred.koenigsrainer@med.uni-tuebingen.de (A.K.); stefan.beckert@sbk-vs.de (S.B.); markus.loeffler@uni-tuebingen.de (M.W.L.)

2 Interfaculty Institute for Cell Biology, Department of Immunology, University of Tübingen, Auf der Morgenstelle 15, 72076 Tübingen, Germany; benedikt.ac.oswald@gmail.com (B.O.); franziska.herster@rbk.de (F.H.); joseph.kauer@med.uni-heidelberg.de (J.K.); rammensee@uni-tuebingen.de (H.-G.R.)

3 Department of Surgery, Klinikum Rechts der Isar, Technical University of Munich (TUM), Ismaninger Str. 22, 81675 Munich, Germany

4 Institute of Nutritional Sciences, Department of Nutritional Biochemistry, University of Hohenheim, Garbenstr. 30, 70599 Stuttgart, Germany; markus.burkard@uni-hohenheim.de (M.B.); sascha.venturelli@uni-hohenheim.de (S.V.)

5 Department of Blood Group Serology and Transfusion Medicine, Medical University of Vienna, Währinger Gürtel 18-20, 1090 Vienna, Austria; alexander.tolios@meduniwien.ac.at

6 Center for Physiology and Pharmacology, Institute of Vascular Biology and Thrombosis Research, Medical University of Vienna, Schwarzspanierstraße 17A, 1090 Vienna, Austria

7 Center for Medical Statistics, Informatics and Intelligent Systems, Institute of Artificial Intelligence, Medical University of Vienna, Spitalgasse 23, 1090 Vienna, Austria

8 Robert Bosch Center for Tumor Diseases (RBCT), Robert Bosch Hospital, Auerbachstr. 110, 70376 Stuttgart, Germany

9 German Cancer Consortium (DKTK) and German Cancer Research Center (DKFZ) Partner Site Tübingen, 72076 Tübingen, Germany; matthias.schwab@ikp-stuttgart.de

10 Clinical Collaboration Unit Translational Immunology, German Cancer Consortium (DKTK), Department of Internal Medicine, University Hospital Tübingen, Otfried-Müller-Str. 10, 72076 Tübingen, Germany

11 Department of Hematology, Oncology, and Rheumatology, University Hospital Heidelberg, Im Neuenheimer Feld 410, 69120 Heidelberg, Germany

12 Department of Surgery, Paracelsus Medical University, Müllner Hauptstraße 48, 5020 Salzburg, Austria; ta.jaeger@salk.at

13 Department of General, Visceral and Thoracic Surgery, Landeskrankenhaus Feldkirch, Carinagasse 47, 6800 Feldkirch, Austria

14 Cluster of Excellence iFIT (EXC2180) 'Image-Guided and Functionally Instructed Tumor Therapies', University of Tübingen, 72076 Tübingen, Germany

15 Department of Vegetative and Clinical Physiology, Institute of Physiology, University of Tübingen, Wilhelmstr. 56, 72074 Tübingen, Germany

16 Department of Clinical Pharmacology, University Hospital Tübingen, Auf der Morgenstelle 8, 72076 Tübingen, Germany

17 Dr. Margarete Fischer-Bosch-Institute of Clinical Pharmacology, Auerbachstr. 112, 70376 Stuttgart, Germany

18 Departments of Pharmacy and Biochemistry, University of Tübingen, Auf der Morgenstelle 15, 72076 Tübingen, Germany

19 Department of General and Visceral Surgery, Schwarzwald-Baar Hospital, Klinikstr. 11, 78052 Villingen-Schwenningen, Germany

* Correspondence: can.yurttas@med.uni-tuebingen.de

Simple Summary: Absence of survival benefits when adding hyperthermic intraperitoneal chemotherapy (HIPEC) with oxaliplatin to cytoreductive surgery in peritoneal metastasis from colorectal cancer has recently been shown in the randomized controlled PRODIGE 7 trial. We therefore aimed to investigate the effects of this treatment modality in a preclinical micrometastasis model. 
Cancer cells were incubated with either patient samples obtained during HIPEC procedures or with defined oxaliplatin-containing solutions prepared according to clinically established HIPEC protocols. Our results demonstrate a limited effectiveness of short-term HIPEC in simulations with oxaliplatin to eliminate micrometastases, although we used platinum-sensitive cell lines for our model. Since these results are in line with findings from current research, our studies might offer further convincing evidence and potential explanations for HIPEC futility observed in clinical application.

\begin{abstract}
Cytoreductive surgery combined with hyperthermic intraperitoneal chemotherapy (HIPEC) was considered a promising treatment for patients with peritoneal metastasis from colorectal cancer. However, the recently published randomized controlled PRODIGE 7 trial failed to demonstrate survival benefits through the addition of short-term oxaliplatin-based HIPEC. Constituting a complex multifactorial treatment, we investigated HIPEC in a preclinical model concerning the elimination of minimal tumor residues, thereby aiming to better understand the size of effects and respective clinical trial results. Patient samples of peritoneal perfusates obtained during HIPEC treatments and oxaliplatin-containing solutions at clinically relevant dosages, conforming with established HIPEC protocols, were assessed regarding their ability to eliminate modelled $\sim 100 \mu \mathrm{m}$ thickness cancer cell layers. Impedance-based real-time cell analysis and classical end-point assays were used. Flow cytometry was employed to determine the effect of different HIPEC drug solvents on tumor cell properties. Effectiveness of peritoneal perfusate patient samples and defined oxaliplatin-containing solutions proved limited but reproducible. HIPEC simulations for $30 \mathrm{~min}$ reduced the normalized cell index below $50 \%$ with peritoneal perfusates from merely 3 out of 9 patients within $72 \mathrm{~h}$, indicating fullthickness cytotoxic effects. Instead, prolonging HIPEC to $1 \mathrm{~h}$ enhanced these effects and comprised 7 patients' samples, while continuous drug exposure invariably resulted in complete cell death. Further, frequently used drug diluents caused approximately $25 \%$ cell size reduction within $30 \mathrm{~min}$. Prolonging oxaliplatin exposure improved effectiveness of HIPEC to eliminate micrometastases in our preclinical model. Accordingly, insufficient penetration depth, short exposure time, and the physicochemical impact of drug solvents may constitute critical factors.
\end{abstract}

Keywords: PRODIGE 7 trial; peritoneal metastasis; peritoneal carcinomatosis; colorectal cancer; micrometastasis model

\title{
1. Introduction
}

The combined use of cytoreductive surgery (CRS) and hyperthermic intraperitoneal chemotherapy (HIPEC) for colorectal cancer (CRC) peritoneal metastasis has been supported by a leadoff randomized controlled trial (RCT) in 2003 showing prolonged overall survival for this treatment compared to palliative chemotherapy alone [1]. For decades this combined treatment approach has been in use for peritoneal metastases of different cancers [2]. The theoretical rationale of HIPEC is the elimination of residual tumor cells remaining after CRS through the locoregional administration of chemotherapy, which is justified by the assumption that a compartmental effect caused by the so-called peritonealplasma barrier prevents the penetration of intravenous drugs into the abdominal space [3]. The most frequent indication for this treatment has been peritoneal metastasis originating from ovarian cancer or CRC as well as pseudomyxoma peritonei. Accordingly, CRS and HIPEC has recently been shown to improve overall survival in a large cohort study in patients with pseudomyxoma peritonei [4] and can be considered the standard of care in this rare malignant syndrome [5]. In spite of long-standing practice, evidence from RCTs was lacking that could confirm survival benefits for adding HIPEC treatment to CRS alone. Only in 2018 an RCT demonstrated an increase in overall survival through adding 90-min cisplatin-based HIPEC to surgery in selected patients suffering from peritoneal metastasis that originated from platinum-sensitive ovarian cancers [6]. Of note, HIPEC treatment remained very heterogeneous over years [2,7]. In this context, the necessity of uniform and comparable treatment protocols has been rarely addressed, although this 
has been done for HIPEC with oxaliplatin (OX) in the treatment of CRC [8]. In contrast, attempts of standardization are commonplace for the surgical approach of CRS in peritoneal metastasis [9] and a required learning curve for improvement is well-established [10,11]. Amongst the numerous protocols in use, one of the most frequently applied drugs for peritoneal metastases in CRC is OX [7,12]. However, the recently published PRODIGE 7 study failed to show a survival benefit for the addition of 30-min OX-based HIPEC compared to surgery alone [13]. This multicenter RCT had used $460 \mathrm{mg}$ OX (i.e., $230 \mu \mathrm{g} / \mathrm{mL} \hat{=} 579 \mu \mathrm{M}$ OX) for open HIPEC (coliseum technique) and $360 \mathrm{mg}$ OX (i.e., $180 \mu \mathrm{g} / \mathrm{mL} \hat{=} 453 \mu \mathrm{M}$ OX) for closed HIPEC, diluted in dextrose solvent with each $2 \mathrm{~L}$ of perfusate filled into the abdomen. Since this outcome was unexpected, many discussions ensued as to why the HIPEC procedure performed so surprisingly poor [14-16]. Remarkably, basic and/or pharmacological research that may have shed more light in this context was unavailable. It should be acknowledged that CRS and HIPEC constitute a complex compound treatment with many variables, hence the single contribution of each of the components remains poorly dissected [17].

For this reason, we were interested to investigate how different OX-containing solutions would perform under simulated HIPEC conditions in a $\sim 100 \mu \mathrm{m}$ thick micrometastasis model. Already in previous work we had established an impedance-based real-time cell analysis (RTCA) assay, enabling continuous monitoring of cancer cells. Hereby, a thorough characterization of patient perfusate samples taken during HIPEC procedures was performed [18]. At this time, we had used respective OX-containing samples diluted with 50\% serum-containing cell culture medium and left them incubated with OAW42 ovarian cancer cells. This assay unanimously showed an elimination of the exposed cell layer within $72 \mathrm{~h}$. The aim of the present study was now to assess HIPEC treatment in a preclinical model to separately characterize its effects within the multimodal therapy approach. To this end, we incubated a $\sim 100 \mu \mathrm{m}$ thick layer of platinum-sensitive tumor cells at $42{ }^{\circ} \mathrm{C}$ for $30 \mathrm{~min}$ or $60 \mathrm{~min}$ with well-defined sample materials previously obtained during HIPEC treatment of patients. We also used OX at clinically relevant concentrations diluted in different solvents, conforming with established HIPEC protocols. This also encompassed the exact OX dosages and diluents that have been reported for the PRODIGE 7 trial [13].

\section{Materials and Methods}

\subsection{Patient Samples}

Studies on materials sampled during patient treatment were approved by the institutional review board at Tübingen University (project number: 367/2013BO1). All patients gave their written informed consent before study inclusion. Patient characteristics and treatment details can be assessed elsewhere [18]. Drug solvent circulated through the abdomen of patients was collected prior to addition of OX $(0 \mathrm{~min})$ as well as OX-containing samples taken at 5, 10, 15, 20, 25, and 30 min after starting the HIPEC procedure. For patient 8 and 9, samples were only obtained in 10-min intervals. Samples were stored at $-80^{\circ} \mathrm{C}$ until usage. Cellular debris and other impurities were cleared by centrifugation ( 5 min at $13,000 \times g$ ) before use.

\subsection{Impedance-Based Real-Time Cell Analysis (RTCA)}

Materials and methods were used as established before [18], with slight modifications. As described previously, platinum-sensitive OAW42 cells (European Collection of Authenticated Cell Cultures, Salisbury, UK) were grown under appropriate conditions, seeded and used as a model system to monitor effects of OX in real-time [18]. In brief, cells were grown in cell culture medium (DMEM; Dulbecco's Modified Eagle Medium, high glucose; Gibco/Life Technologies, Carlsbad, CA, USA, adding 10\% fetal calf serum (FCS); Sigma-Aldrich/Merck Life Science, St. Louis, MO, USA; 100 U/mL penicillin G; PAA, Pasching, Austria; and $100 \mu \mathrm{g} / \mathrm{mL}$ streptomycin; PAA). Cell cultures were periodically tested for mycoplasma using commercially available polymerase chain reaction (PCR) kits (Minerva Biolabs, Berlin, Germany). An RTCA device (xCELLigence SP; Roche, Grenzach- 
Wyhlen, Germany) was employed as previously described [18]. After a calibration of the device with $100 \mu \mathrm{L}$ DMEM (blank values), $5 \times 10^{4}$ OAW42 cells/ well were seeded into dedicated 96-well plates (E-plate 96; ACEA, San Diego, CA, USA) and left to adhere for $24 \mathrm{~h}$. Subsequently, fluid was discarded from wells and adherent cells were washed once with warmed Dulbecco's phosphate-buffered saline (PBS; Gibco Life Technologies, Carlsbad, CA, USA). Then, either $200 \mu \mathrm{L}$ of peritoneal perfusate obtained during HIPEC from patients or defined concentrations of OX (Oxaliplatin-GRY/ oxaliplatin $5 \mathrm{mg} / \mathrm{mL}$; Teva, Petach Tikwa, Israel/ Fresenius Kabi, Bad Homburg, Germany; dose range: $5.6-230 \mu \mathrm{g} / \mathrm{mL} \hat{=} 14-579 \mu \mathrm{M}$ OX) diluted in peritoneal dialysis fluid (PDS; Physioneal 40 Glucose $2.27 \% \mathrm{~m} / v$; Baxter, Deerfield, IL, USA) or dextrose 5\% in water (D5W; Glucosteril 5\%; Fresenius Kabi) were added. Likewise, adequate controls were employed, including $1 \%(v / v)$ Triton X-100 (Sigma) as a positive control (lysis control for dead cells) and negative controls with either PDS or DMEM only. HIPEC conditions were subsequently simulated by incubating cells for $30 \mathrm{~min}$ or $60 \mathrm{~min}$ at $42{ }^{\circ} \mathrm{C}$ in an ambient air incubation shaker (Infors, Bottmingen, Switzerland) with slight movement (50 rotations per min; rpm). Afterwards, liquids were discarded by flicking and cells were washed twice in PBS and then cultivated in appropriate medium. All samples were analyzed at least in duplicates and impedance was measured continuously in 15-min intervals. Technical errors and outliers were removed. For interexperiment comparability, the cell index was set to 1 immediately before simulated HIPEC treatment (normalized cell index; $\mathrm{nCI}$ ). Results were analyzed using RTCA software (V. 1.2.1). GraphPad prism software (V. 7.01; GraphPad software Inc., La Jolla, CA, USA) was used for presentation of results. In addition, biorender software was used for visualizations (www.biorender.com). Findings of multiple experiments were combined, when adequate.

\subsection{CellTiter-Blue ${ }^{\circledR}$ (CTB) Cell Viability Assay}

To confirm effects detected by RTCA on cell viability, CTB Cell Viability Assay (Promega, Mannheim, Germany) was performed. OAW42 and HT29 cells were seeded in 24-well plates $\left(3.15 \times 10^{5}\right.$ cells) in a volume of $500 \mu \mathrm{L}$ in triplicates and incubated overnight at $37^{\circ} \mathrm{C}$ and $5 \% \mathrm{CO}_{2}$ in a humidified atmosphere. To mimic different HIPEC treatment conditions, DMEM was discarded, cells were washed with PBS and then incubated for $30 \mathrm{~min}$ at $42{ }^{\circ} \mathrm{C}$ under ambient air conditions with OX (at concentrations of $45,90,180$, and $230 \mu \mathrm{g} / \mathrm{mL} ; \hat{=} 113,227,453$, and $579 \mu \mathrm{M}$ OX) diluted either in D5W, PDS, or DMEM (control). Following treatment, solutions were discarded and replaced by $500 \mu \mathrm{L}$ of fresh DMEM after washing with PBS and incubated for $72 \mathrm{~h}\left(37^{\circ} \mathrm{C} ; 5 \% \mathrm{CO}_{2}\right)$. In parallel, OXspiked DMEM remained on the cells to verify OX toxicity on OAW42 and HT29 cells after $72 \mathrm{~h}$ continuous exposure $\left(37^{\circ} \mathrm{C} ; 5 \% \mathrm{CO}_{2}\right)$. As positive controls, cell death was induced by lysing cells with $1 \%(v / v)$ Triton X-100 (Roth, Karlsruhe, Germany) for $10 \mathrm{~min}$ immediately prior to CTB staining. To determine cell viability, $100 \mu \mathrm{L}$ of assay reagent were added and gently mixed. Fluorescence measurement was performed $1 \mathrm{~h}$ after incubation $\left(37{ }^{\circ} \mathrm{C} ; 5 \% \mathrm{CO}_{2}\right)$ for each cell line with the Synergy HT microtiter plate reader (BioTek Instruments Inc., Winooski, VT, USA; record fluorescence; excitation wavelength: 530/25 and emission wavelength: 590/35, adjusted sensitivity: 35). CTB assays were repeated in 3 independent experiments.

\subsection{Sulforhodamine B (SRB) Cytotoxicity Assay}

OAW42 and HT29 cells were seeded in 24-well plates $\left(3.15 \times 10^{5}\right.$ cells/ well $)$ in a volume of $500 \mu \mathrm{L}$ as triplicates and incubated overnight $\left(37^{\circ} \mathrm{C} ; 5 \% \mathrm{CO}_{2}\right)$. To mimic HIPEC treatment, medium was discarded, and cells were washed with PBS and then incubated for $30 \mathrm{~min}$ at $42{ }^{\circ} \mathrm{C}$ under ambient air conditions with OX diluted either in D5W, PDS, or DMEM (see OX concentrations given above). After treatment, solutions were discarded and replaced by $500 \mu \mathrm{L}$ of fresh DMEM after washing with PBS and incubated for $72 \mathrm{~h}$ $\left(37^{\circ} \mathrm{C} ; 5 \% \mathrm{CO}_{2}\right)$. In a parallel experiment, OX-spiked DMEM remained on the cells to verify OX effects on OAW42 and HT29 cells after $72 \mathrm{~h}$ exposure $\left(37^{\circ} \mathrm{C} ; 5 \% \mathrm{CO}_{2}\right)$. As positive control, cell death was induced by lysing cells with $1 \%(v / v)$ Triton X-100 (Roth, Karlsruhe, 
Germany) for $10 \mathrm{~min}$ immediately prior to SRB staining. Finally, growth inhibition was evaluated by SRB assay. In brief, medium was discarded, and each well was washed once with ice-cold PBS and fixed with $10 \%$ trichloroacetic acid (TCA) for $30 \mathrm{~min}$ at $4{ }^{\circ} \mathrm{C}$. After washing with tap water, cells were dried at $40{ }^{\circ} \mathrm{C}$ overnight. Then proteins were stained for $10 \mathrm{~min}$ with SRB reagent $(0.4 \%(w / v)$ in $1 \%(v / v)$ acetic acid; CAS 3520-42-1, Sigma-Aldrich) and after removing unbound dye with tap water followed by $1 \%(v / v)$ acetic acid, dried again at $40^{\circ} \mathrm{C}$. Protein-bound dye was resolved with $10 \mathrm{mM}$ Tris base (pH 10.5). After $10 \mathrm{~min}$ incubation at room temperature, optical density was measured in triplicates ( $80 \mu \mathrm{L}$ volume / well) in 96-well plates with a Synergy HT microtiter plate reader (BioTek Instruments; measurement wavelength $550 \mathrm{~nm}$, reference wavelength $620 \mathrm{~nm}$ ). Data represent the mean of optical density values related to DMEM treated control cells. SRB assays were repeated in 3 independent experiments.

\subsection{Microscopy}

In order to obtain a serial dilution, OAW42 cells were seeded at different numbers of $12.5 \times 10^{3}, 20 \times 10^{3}, 25 \times 10^{3}, 35 \times 10^{3}$, and $50 \times 10^{3}$ cells/ well (96-well flat bottom plate) and incubated in $200 \mu \mathrm{L}$ DMEM. After $24 \mathrm{~h}$ of cell culture, cells were carefully washed with PBS and subsequently treated with fixation buffer (BioLegend, San Diego, CA, USA) for $10 \mathrm{~min}$ at room temperature, carefully washed again and kept at $4{ }^{\circ} \mathrm{C}$ prior to measurements. Experiments were performed twice. The thickness of cell layers was obtained measuring z-stacks on a Nikon Ti Eclipse microscope (by an unbiased observer) using $10 \times$ magnification. The analysis was performed with the NIS-Elements (Nikon, Tokyo, Japan) or ImageJ software V. $1.52 \mathrm{~h}$.

\subsection{Flow Cytometry}

OAW42 cells were seeded in 96-well plates $\left(1 \times 10^{5}\right.$ cells/ well $)$ in either $200 \mu \mathrm{L}$ of DMEM, PDS, or D5W and kept for $30 \mathrm{~min}$ or $60 \mathrm{~min}$ at $42{ }^{\circ} \mathrm{C}$. Immediately prior to flow cytometric analysis, 7-amino-actinomycin D viability staining solution (7-AAD; BioLegend) was added to each well at a final concentration of $600 \mathrm{ng} / \mathrm{mL}$. Dead cells (7-AAD-positive) as well as doublets were excluded. Forward scatter area (FSC-A) served as an indicator for cell size. Samples were analyzed using a FACSCanto II (BD Biosciences, Heidelberg, Germany) and data analysis was performed using FlowJo_V9 software (FlowJo LCC, Ashland, OR, USA). Flow cytometric analysis of cell size under HIPEC conditions was repeated in independent experiments.

\section{Results}

\subsection{Monitoring HIPEC Effects in a Micrometastasis Model in Real-Time by} Impedance Assessment

The 2-dimensional (2D) micrometastasis model as established here aims to recreate the clinical conditions prevailing during HIPEC in a laboratory setting. Not only are cells exposed to hyperthermia and realistic drug dosages but also exposure time and respective solvents can be modelled with either patient samples or OX-containing solutions prepared appropriately in this preclinical model. Of note, the used RTCA system allows continuous monitoring of cell elimination and addresses the clinically relevant question of effectiveness in peritoneal micrometastases after optimal CRS (Figure 1). For this reason, our model system used a cell layer with defined thickness, requiring a penetration depth of about $100 \mu \mathrm{m}$ for measurable effects (Figure S1). 


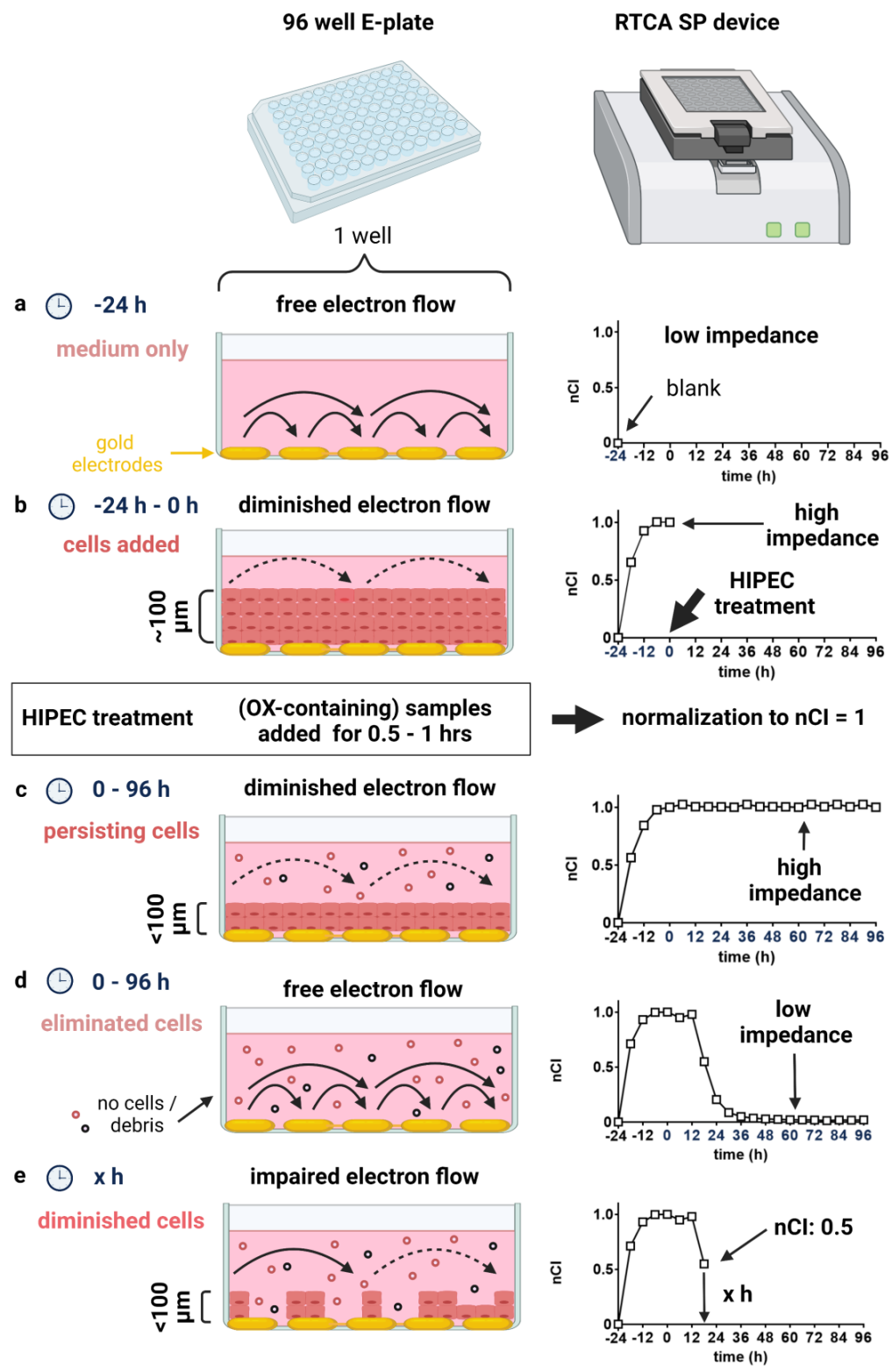

Figure 1. Background on the used micrometastasis model and readout of the used real-time impedancebased cell analysis (RTCA) assay. (a) The experiment in a 96-well E-plate is started $24 \mathrm{~h}$ before the planned HIPEC treatment. Blank values with only cell culture medium are measured. Under these conditions, electrons can flow freely between the gold electrodes located at the well bottom (baseline; low impedance). (b) Subsequently, cells are added to each well and left to attach for $24 \mathrm{~h}$ forming a $\sim 100 \mu \mathrm{m}$ thick cell layer (impedance increases to reach a plateau, since electron flow is heavily impaired through the isolation effects of the added cells). At this point, before HIPEC simulation (b), impedance is normalized to 1 $(\mathrm{nCI}=1)$ to allow for comparability between independent experiments. (c) HIPEC simulation is performed by incubating cells with OX-containing solutions for $30 \mathrm{~min}$ or $60 \mathrm{~min}$ at $42{ }^{\circ} \mathrm{C}$ with slight movement. Afterwards samples are removed, cells washed and supplemented with fresh medium. Measurement is continued for 4 days. (d) If the complete full cell layer is affected, and cells become penetrable in full thickness, while only debris remains, electrons can flow freely, and impedance decreases to baseline values. (e) If cells persist and isolation effects impairing free electron flow remain, impedance diminishes depending on intact cells left. An $\mathrm{nCI}=0.5$ specifies the value when the initial impedance has been bisected and can be determined as a function of time. The thickness of the seeded cells was assessed and the linearity of thickness according to cell numbers seeded per well established (Figure S1). For a relatable scale, the edge length of a grain of salt is about $300 \mu \mathrm{m}$. 
The RTCA readout is generated by measuring electron flow between an array of electrodes located at the bottom of each well in a specific 96-well E-Plate (Figure 1a). An intact cell layer isolates the electrodes and thereby impairs electron flow. Accordingly, impedance increases, which is indicated by a rising cell index (Figure $1 b, c$ ). This effect is proportional to the cell number and morphology of cells covering the electrodes at the well bottom (Figure 1e) [19]. In our model, relevant measurable effects require full thickness defects of the cell layer (decline in cell index Figure 1d). An nCI value of 0.5 specifies that the initially prevailing impedance measured at normalization has been bisected.

\subsection{Modelling HIPEC with Patient Samples Displays Heterogeneous Effectivity (by RTCA Assay) in a Micrometastasis Model}

First, we used sample materials that were obtained during OX-based HIPEC from 9 patients and that have been extensively characterized previously [18]. As shown before, the label-free RTCA assay enables monitoring cells continuously with good temporal resolution. However, now we intended to model HIPEC conditions more precisely and exposed ovarian cancer cells (OAW42) to respective aliquots from HIPEC patient samples for $30 \mathrm{~min}$ or $60 \mathrm{~min}$ at $42{ }^{\circ} \mathrm{C}$ (50 rpm shaking) to simulate respective conditions, subsequently washing cells and extending cell culture with fresh culture medium and regularly assessing $\mathrm{nCI}$ values (Figure 2a).

Previously published experiments have shown that these exact OX-containing samples invariably eliminated the seeded cells, when continuously exposing them for $72 \mathrm{~h}$ to HIPEC perfusates, even when diluting them through supplementation of 50\% medium [18].

a
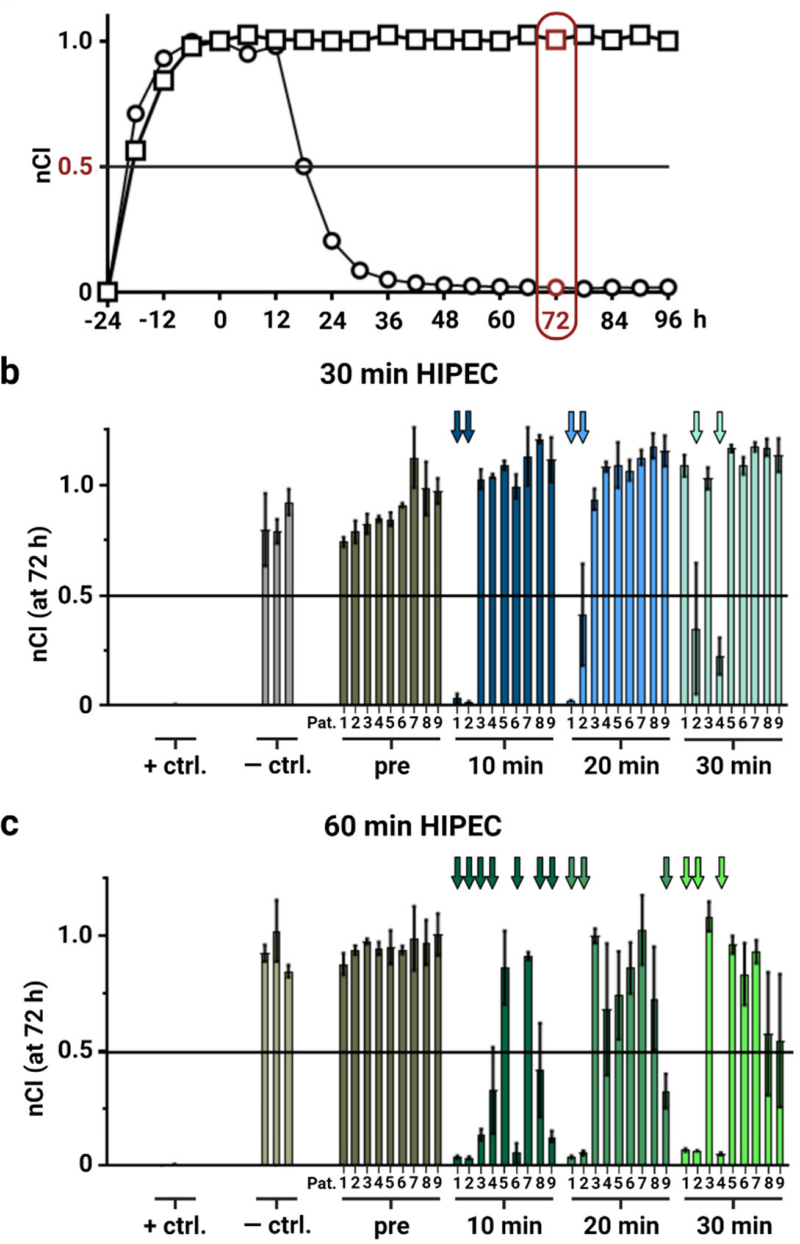

Figure 2. Cont. 
d

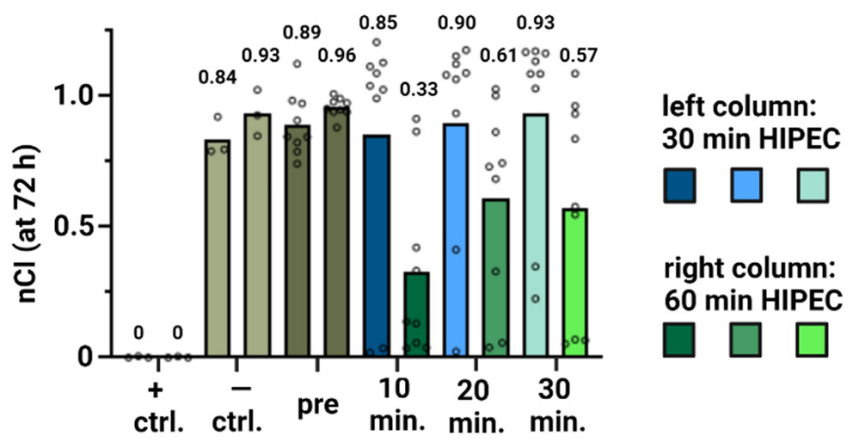

Figure 2. HIPEC simulations using patient samples (RTCA assay). (a) Exemplary impedance readings in 12-h intervals. The displayed time point $72 \mathrm{~h}$ after HIPEC simulation is marked by a red border. (b,c) Simulated HIPEC $\left(42^{\circ} \mathrm{C}\right.$ at $50 \mathrm{rpm}$ shaking) was performed, either for $30 \mathrm{~min}(\mathbf{b})$ or for $60 \mathrm{~min}$ (c) with $5 \times 10^{4}$ OAW42 cells per well. (d) Means of replicate values shown in (b,c) are annotated as dots and respective overall mean values of different patient materials are shown as a bar plot and annotated (left bars/ blue colors: 30 min exposure in HIPEC simulations; right bars/green colors: 60 min exposure in HIPEC simulations). Due to the large variance and partly bimodal data distribution, any statistical significance testing was omitted and means chosen as a measure of central tendency. X-axis: positive control (+ ctrl.) with Triton X-100, negative control ( - ctrl.) (light grey coloration) and HIPEC solutions obtained from patients (Pat.) 1-9 each: samples before/pre (dark grey coloration), $10 \mathrm{~min}$ (dark blue/ dark green coloration), $20 \mathrm{~min}$ (medium blue/ medium green coloration), and $30 \mathrm{~min}$ (light blue/ light green coloration) after adding OX to the HIPEC circuit during patient treatment. Y-axis: $\mathrm{nCI}$ determined at $72 \mathrm{~h}$ since beginning of measurements after HIPEC treatment. Each colored arrow marks an average decrease in $\mathrm{nCI}(72 \mathrm{~h}$ ) below 0.5 (black horizontal line). Depiction of mean values with standard deviation, number of replicates: 2-5.

In our modified HIPEC model, most aliquots from the previously characterized patient samples [18] proved insufficient to effectively eliminate the cancer cells in our micrometastasis model within $72 \mathrm{~h}$, when HIPEC was simulated for $30 \mathrm{~min}$. Strikingly, in 6 out of 9 investigated patients, none of the obtained OX-containing samples tested was able to reduce impedance below $50 \%$ of initial values $(\mathrm{nCI}<0.5)$ within 3 days following HIPEC simulation (Figure $2 \mathrm{~b}$ ). Prolonging exposure time to $1 \mathrm{~h}$ considerably improved cytotoxic effects but did not prove generally effective, lowering $\mathrm{nCI}<0.5$ when using samples from 7 out of 9 patients (Figure 2c). Observed effects were also stronger in those samples that were taken earlier after HIPEC initiation during clinical patient treatment. Further, using the overall means from different patient samples and comparing the different conditions to each other (Figure 2d) revealed clear differences between $30 \mathrm{~min}$ and $60 \mathrm{~min}$ of OX-based HIPEC simulation. When considering effects after $30 \mathrm{~min}$ exposure, both controls and HIPEC perfusates sampled at different time points showed comparable mean nCI readings ranging from 0.84 to 0.96 at $72 \mathrm{~h}$ following the treatment. In contrast, prolonging the procedure to 60 min resulted in mean $\mathrm{nCI}$ readings of 0.33 with OX-containing HIPEC perfusates sampled in patients after $10 \mathrm{~min}$ as well as decreasing mean $\mathrm{nCI}$ values to 0.61 (20 $\mathrm{min})$ and 0.57 (30 $\mathrm{min})$ for respective samples obtained later. Although it has to be mentioned that the source data partly show a bimodal distribution as well as a large variance (see also Figure 2c), this evaluation supports improved effects with increased HIPEC duration as well as underscoring patient individual differences.

The differences in our micrometastasis model for the perfusates sampled in patients at several different time points during HIPEC and used for short-term (30 min) and prolonged (60 min) HIPEC simulations are striking. Looking at the RTCA results from perfusate samples in 2 exemplary patients, we can discern in patient 3 (Figure 3a) that with none of the OX-containing perfusates the exposed cell layer could be effectively eliminated following $30 \mathrm{~min}$ of simulated HIPEC, as shown by persistently elevated impedance readings. Prolonging the treatment duration to $1 \mathrm{~h}$ could rescue these effects and showed 
a decrease below $\mathrm{nCI}=0.5$ for the samples obtained during the first 15 min of clinical HIPEC treatment in this patient, whereas the other samples (20-30 min) proved ineffective. In contrast, patient 1 already showed a respective decrease of $\mathrm{nCI}$ to baseline values after $30 \mathrm{~min}$ of simulated HIPEC for all samples obtained during the first $20 \mathrm{~min}$ of the HIPEC procedure in the clinic (Figure $3 b$ ). Here, a prolonged exposure of cells to HIPEC samples over $1 \mathrm{~h}$ showed impedance decreasing to baseline values in all OX-containing perfusates tested.

For a comparison of aliquots from the same sample materials of the 2 presented patients, contrasting both $30 \mathrm{~min}$ and $60 \mathrm{~min}$ of simulated HIPEC to continuous exposure, we annotated the time points when $\mathrm{nCI}=0.5$ was reached in an overview chart (Figure $3 \mathrm{c}$; patient samples are aliquots from the materials previously characterized and data of continuous incubation were previously published by Löffler et al. [18]).

On a side note, the perfusate used for continuous exposure of cells had to be diluted with medium $(50 \%)$, since this is inevitably required to sustain cell culture. Respective samples therefore contain only half of the OX concentrations compared to those samples used for $30 \mathrm{~min}$ and $60 \mathrm{~min}$ of simulated HIPEC (Figure 3c). Still, continuous exposure to OX-containing HIPEC perfusates unanimously led to nCI decreases below 0.5. This was usually reached within $48 \mathrm{~h}$ with a slight waning effect over time for perfusates sampled later during HIPEC in patients. A complete dataset with results from the other patients is provided in the Supplementary Materials (Figures S2-S15). Further, it has been established that only $0.05 \mu \mathrm{M}$ OX is sufficient to kill $50 \%$ of directly exposed OAW42 cells $\left(\mathrm{LC}_{50}\right)$ within $72 \mathrm{~h}$ [20], whereas usual OX concentrations used during HIPEC are above $90 \mu \mathrm{M}$ and reach up to $579 \mu \mathrm{M}$ according to the PRODIGE 7 protocol [13].

\subsection{Short-Term HIPEC with OX-Containing Solutions Prepared According to Clinically Established Protocols Proves Ineffective in Modelled Micrometastases (RTCA Assay)}

Next, we prepared defined OX-containing solutions that comprised accurate amounts of OX in different diluents, aiming to recreate the clinical conditions prevailing during HIPEC as authentically as possible. To this end, we used a concentration range of OX, encompassing the final drug dosages according to most established HIPEC protocols [16], explicitly including those used in the PRODIGE 7 study [13] and conforming with previously published HIPEC models [21].

We assessed the effects of respective OX concentrations diluted either in D5W or PDS in our $100 \mu \mathrm{m}$ thickness micrometastasis model after simulating the HIPEC procedure for $30 \mathrm{~min}$. Subsequently, drugs were removed, and cells were washed and cultured in medium for the long-term.

Here, we did not observe any substantial treatment induced decrease in nCI after 30 min of OX-based HIPEC using either D5W (Figure 4a) or PDS (Figure 4b) as a solvent within $96 \mathrm{~h}$ following treatment, with the exception of the highest dosage of $230 \mu \mathrm{g} / \mathrm{mL} \mathrm{OX}$ diluted in PDS. Prolongation to $60 \mathrm{~min}$ simulated HIPEC showed effective for $180 \mu \mathrm{g} / \mathrm{mL}$ and $230 \mu \mathrm{g} / \mathrm{mL}$ OX when diluted with PDS (see Supplementary Materials: Figure S16). However, 60 min HIPEC exposure with OX diluted in D5W proved technically unfeasible due to recurring detachment of the treated cell layer.

Again, when exposing cells continuously to $\mathrm{OX}$ at the specified concentrations diluted in cell culture medium (here doubled concentrations were used to account for 50\% dilution with medium), this intervention proved effective to reduce $\mathrm{nCI}$ below 0.5 for a broad concentration range. For example, concentrations of $11.2-230 \mu \mathrm{g} / \mathrm{mL}$ OX proved effective when diluted in D5W and for $22.5-230 \mu \mathrm{g} / \mathrm{mL}$ in PDS. For the dose range of $22.5-45 \mu \mathrm{g} / \mathrm{mL}$ OX it appears that dilution in PDS reached $\mathrm{nCI}=0.5$ slightly faster than with D5W. Further higher drug concentrations seemed associated with reaching $\mathrm{nCI}=0.5$ earlier than when using a lower drug concentration. However, measurable effects still took several hours to appear. 
a
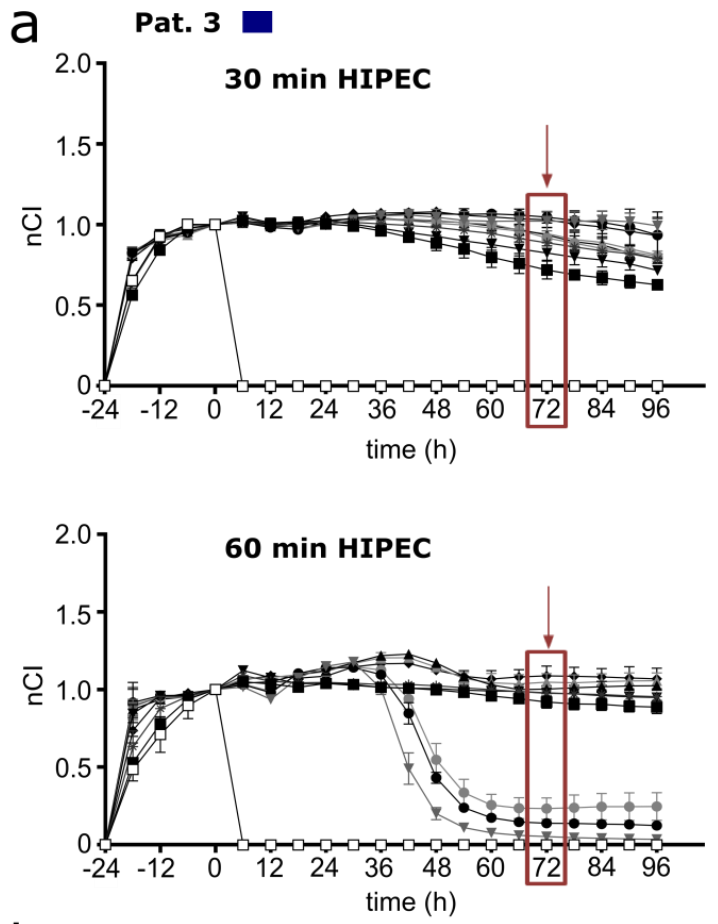

b

Pat. 1
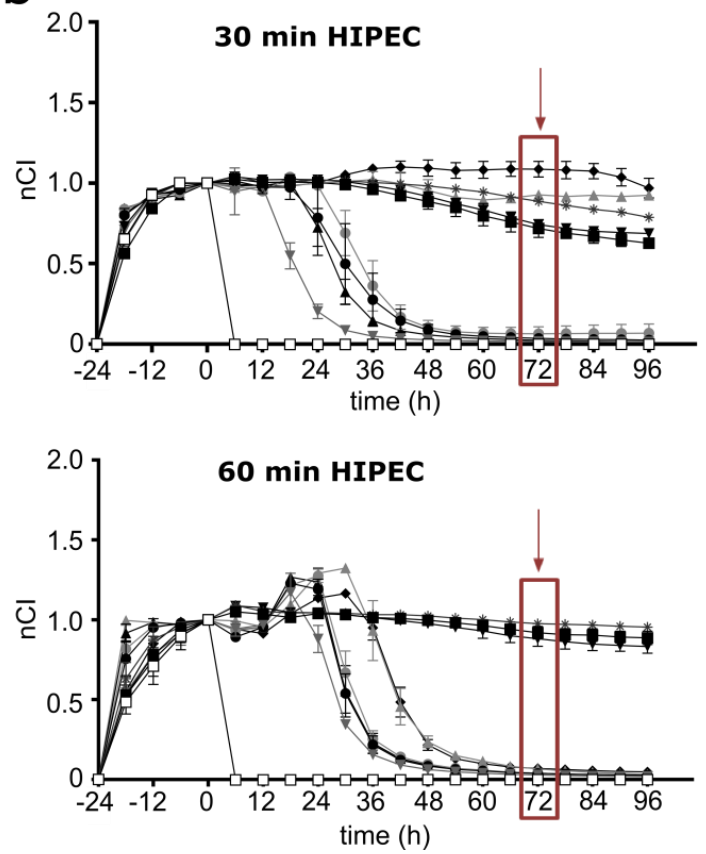

Legend:

$$
\begin{array}{ll}
\text { controls } & \begin{array}{c}
\text { sampling after } \\
\text { HIPEC start }
\end{array} \\
-\square+\text { ctrl. } & \rightarrow 5 \mathrm{~min} \\
-- \text { ctrl. } & \bullet-10 \mathrm{~min} \\
* \text { MEM } & \bullet-15 \mathrm{~min} \\
\rightarrow \text { pre } & \leftarrow 20 \mathrm{~min} \\
& \leftarrow 25 \mathrm{~min} \\
& \rightarrow-30 \mathrm{~min}
\end{array}
$$

C
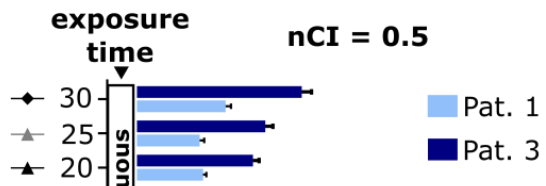

$-15-\square$

- 10 ए

$\rightarrow 5-\square$

$\rightarrow$ pre

- 30

$\triangle 25$

$+20$

- 15

- 10

$\rightarrow 5$

$\rightarrow$ pre

$\rightarrow 30$

$\star 25$

$-20-$

- $15-10$

$\rightarrow$ pre-

$\Delta$

sampling

(min.)
Pat. 3

Figure 3. HIPEC simulations for $30 \mathrm{~min}$ or $60 \mathrm{~min}$ using patient samples (RTCA assay) (a,b) Simulated HIPEC ( $42{ }^{\circ} \mathrm{C}$ at $50 \mathrm{rpm}$ shaking) was performed for $30 \mathrm{~min}$ (upper graph) and $60 \mathrm{~min}$ (lower graph) with $5 \times 10^{4}$ OAW42 cells per well. Positive control (+ ctrl.) with Triton X-100, negative control (- ctrl.) with PDS (peritoneal dialysis solution), MEM (cell culture medium), and HIPEC solutions obtained from patient (Pat.) 3 (a) and Pat. 1 (b). Samples: before (pre), 5, 10, 15, 20, 25, and $30 \mathrm{~min}$ after adding OX to the HIPEC circuit during clinical patient treatment. $Y$-axis: nCI determined until $96 \mathrm{~h}$ after restarting measurements following HIPEC treatment. (c) Duration until $\mathrm{nCI}=0.5$ was reached after $30 \mathrm{~min}$ or $60 \mathrm{~min}$ simulated HIPEC or by continuous incubation (nota bene: dilution with 50\% MEM) with respective samples. Depiction of mean values with standard deviation, number of replicates: $2-4$. Respective RTCA readings with HIPEC sample materials obtained from Pat. 2 and Pat. 4-9 are provided as Supplementary Materials (Figures S2-S15). 

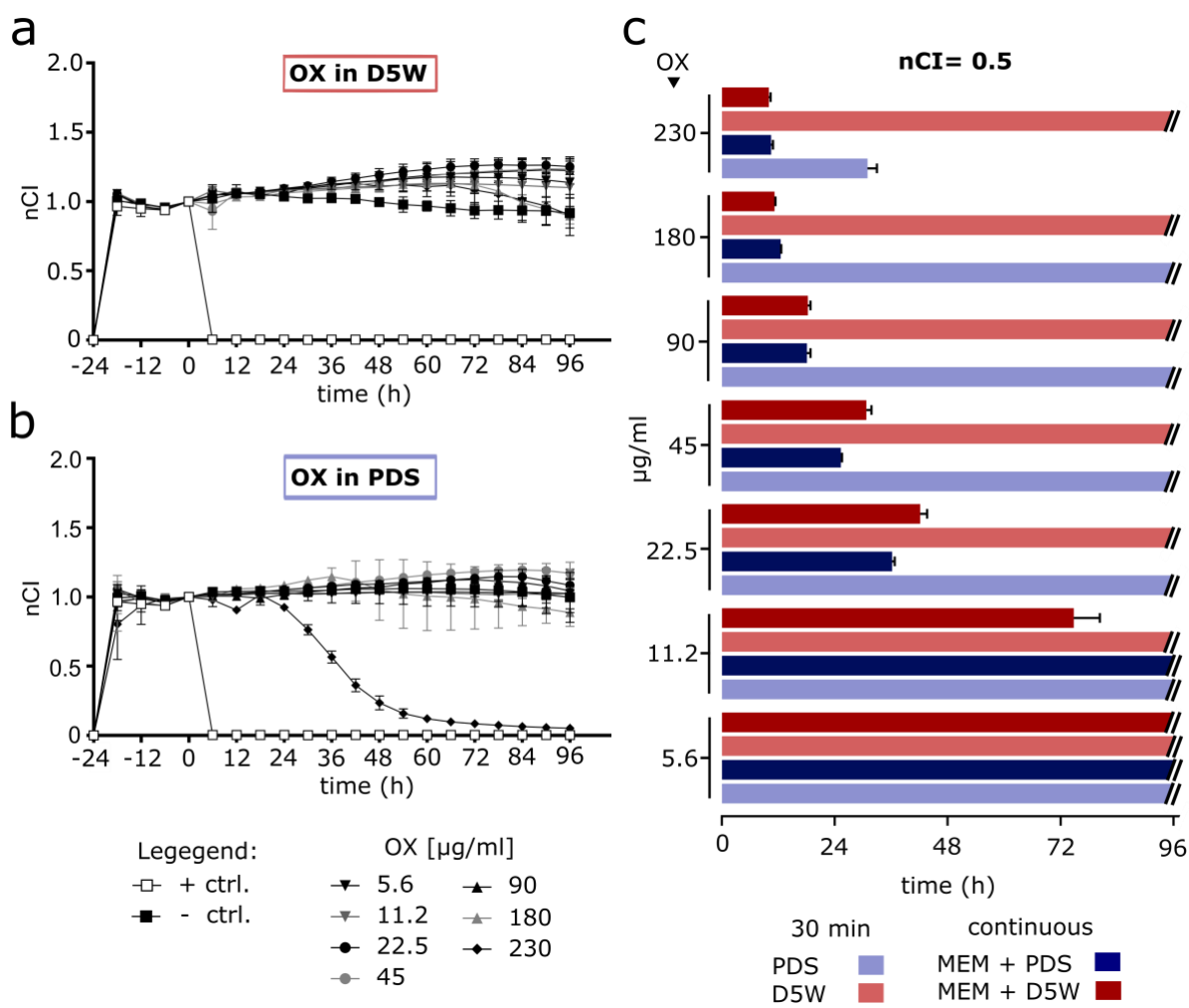

Figure 4. HIPEC simulation for $30 \mathrm{~min}$ using prepared OX-containing solutions (RTCA assay) $(\mathbf{a}, \mathbf{b})$ Simulated HIPEC $\left(42^{\circ} \mathrm{C}\right.$ and $50 \mathrm{rpm}$ shaking) was performed for $30 \mathrm{~min}$ with $5 \times 10^{4} \mathrm{OAW} 42$ cells per well. Positive control (+ ctrl.) with Triton X-100, negative control ( - ctrl.) and prepared solutions with specified OX concentrations in dextrose 5\% (D5W) (a) or peritoneal dialysis solutions (PDS) (b). Y-axis: nCI determined until $96 \mathrm{~h}$ (h) after restarting measurements following HIPEC treatment. (c) Duration until $\mathrm{nCI}=0.5$ was reached after 30 min simulated HIPEC or when continuously incubated (dilution with 50\% cell culture medium (MEM)) with respective samples. Depiction of mean values with standard deviation, number of replicates: 2-3. Respective RTCA readings with continuous OX exposure are provided as Supplementary Materials (Figures S17 and S18).

\subsection{Confirming RTCA Results with Prepared OX-Containing Solutions by Classical End-Points Assays}

To confirm the RTCA results previously obtained, we performed 2 different wellestablished conventional end-point assays. The fluorometric assay CTB is based on the conversion of resazurin to resorufin, occurring only in living cells [22], and a cytotoxicity assay using SRB, which binds stoichiometrically to proteins under mild acidic conditions [23]. Cells were densely seeded to reach comparable conditions as used previously in the RTCA assays. To broaden our analysis, we also added the human colon cancer cell line HT29 [24], which is part of the NCI60 human tumour cell line anticancer drug screen panel and therefore well characterized [25]. The $\mathrm{LC}_{50}$ for OX in HT29 has been established at $72.44 \mu \mathrm{M}$ [26].

After simulated HIPEC for 30 min with $45-230 \mu \mathrm{g} / \mathrm{mL}$ OX diluted in PDS and subsequently culturing the washed cells in medium, both the OAW42 and the HT29 cell lines showed no reduction of mean cell viability below $50 \%\left(\mathrm{LC}_{50}\right)$ in none of the assessed conditions within 3 days after treatment (Figure 5a). This finding applied to both assays performed. Repeating the experiments under identical conditions with OX diluted in D5W solution failed also to induce $\mathrm{LC}_{50}$ at $72 \mathrm{~h}$ following treatment for all tested concentrations (Figure 5b). In contrast, when OX was spiked into cell culture medium (to allow for extended cultivation) and remained with the cells, both cell lines showed clearly enhanced induction of cell death (Figure 5 c). Cell viability reproducibly fell below $\mathrm{LC}_{50}$ values 
within 3 days after exposure to all drug concentrations investigated, with the exception of $45 \mu \mathrm{g} / \mathrm{mL}$ OX in medium when tested on HT29 cells. Findings proved reproducible as the results were comparable for both assays.

a

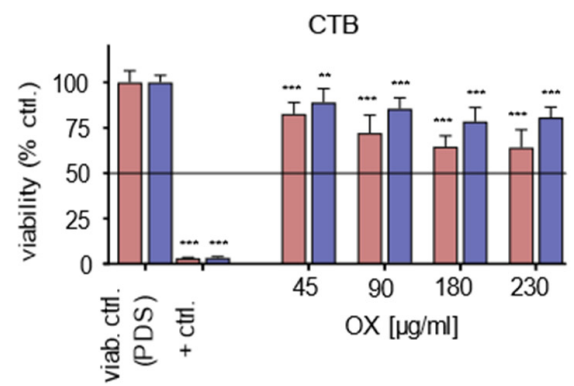

PDS - 30 min HIPEC

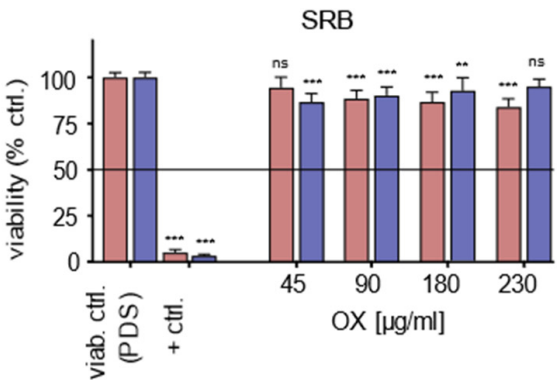

b

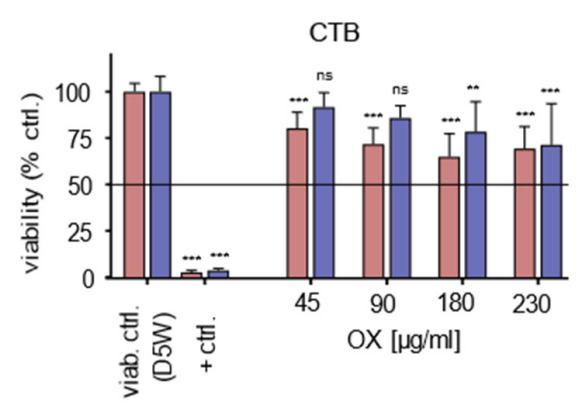

D5W - 30 min HIPEC

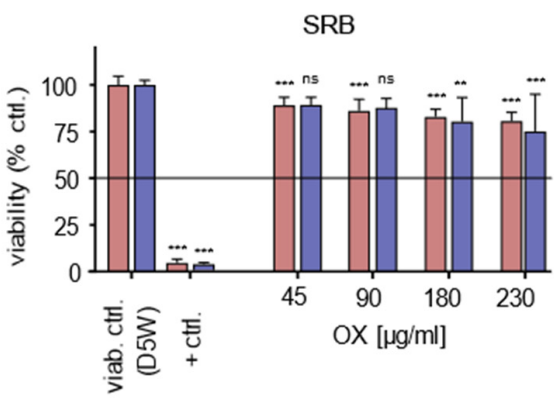

C

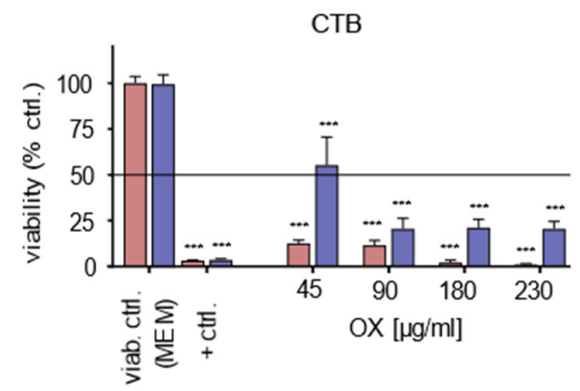

MEM - Continous exposure

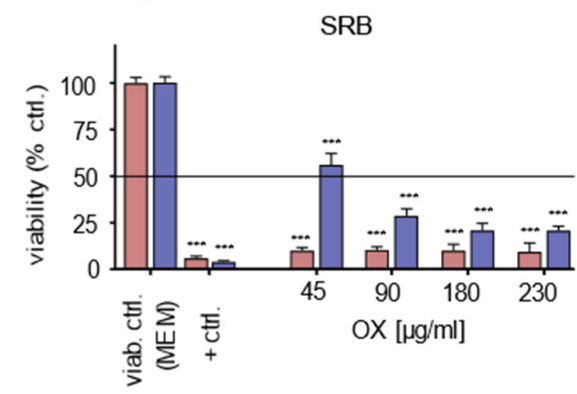

Figure 5. HIPEC simulation for $30 \mathrm{~min}$ using prepared OX-containing solutions diluted either in PDS or D5W (CTB and SRB assay). OAW42 cells (red coloration) as well as HT29 cells (blue coloration) were used at a density of $3.15 \times 10^{5}$ cells per well (in a 24-well format) to recreate the conditions encountered in RTCA assays before. HIPEC was simulated for $30 \mathrm{~min}$ at $42{ }^{\circ} \mathrm{C}$ with prepared solutions containing the specified amounts of OX diluted either in PDS (a) or in D5W (b). After exposure, cells were washed and subsequently cultured in cell culture medium (MEM) for another 3 days. Further, respective cells were incubated continuously with the specified amounts of OX, spiked into MEM to allow for continuous cell culture and heated likewise $\left(30 \mathrm{~min}\right.$ at $42{ }^{\circ} \mathrm{C}$ ) followed by $72 \mathrm{~h}$ cell culture (c). Thereafter, the CTB cell viability assay (left graphs) or the SRB cytotoxicity assay (right graphs) were used. Cells were normalized to cells treated identically with D5W, PDS, and MEM only (viab. ctrl.). Positive control (+ ctrl.) was carried out with $1 \%(v / v)$ Triton X-100. Statistical analysis was performed using the Dunnet's multiple comparison test, confidence interval 95\%. ns: $p \geq 0.05 ;{ }^{* *}: p<0.01 ;{ }^{* * *}: p<0.001$ vs. the respective viability control. The $\mathrm{LC}_{50}$ threshold is marked with a black line. Depiction of mean values with standard deviation from 3 independent experiments, with triplicate values assessed in each experiment performed. 


\subsection{Drug Solvents Used for HIPEC Reduce Cell Size}

OAW42 cells were exposed to D5W and PDS at $42{ }^{\circ} \mathrm{C}$ for either $30 \mathrm{~min}$ or $60 \mathrm{~min}$ and cell size was measured by flow cytometry, since respective solvents constitute the most frequently used drug diluents for HIPEC with OX. Significant cell size reduction of about 25\% (in FSC-A) was observed after $30 \mathrm{~min}$ and $60 \mathrm{~min}$ of incubation at hyperthermic conditions with both solvents tested (D5W and PDS), when compared to cells maintained in cell culture medium (Figure 6). The observed effects are comparable between both solvents and showed only a slightly more increased shrinkage after $1 \mathrm{~h}$ as compared to 30 min exposure.

a

30 min HIPEC
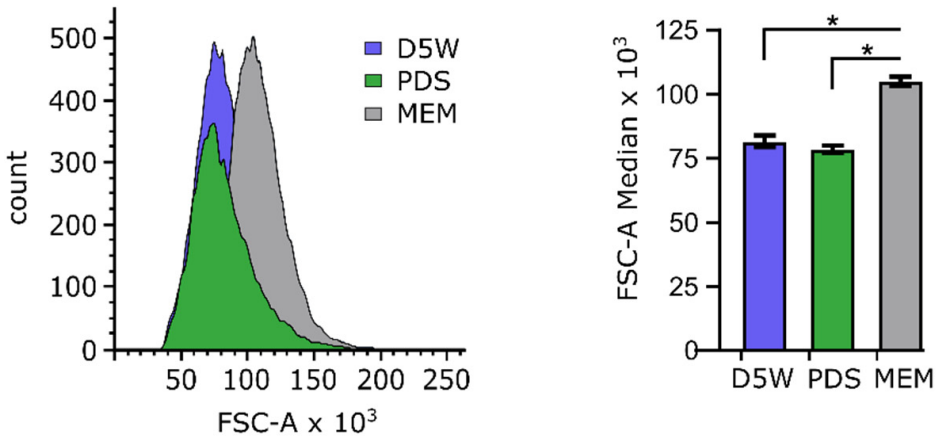

b

60 min HIPEC
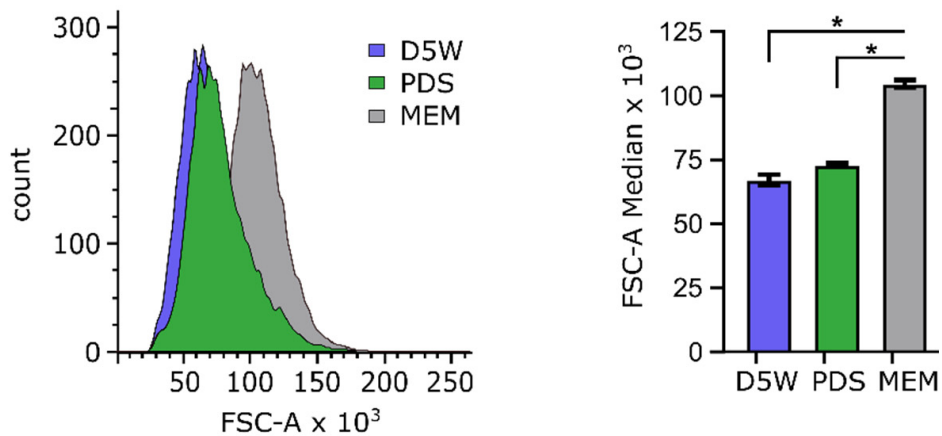

Figure 6. Flow cytometry of OAW42 cells after exposure to different drug diluents for $30 \mathrm{~min}$ or 60 min under hyperthermic conditions. OAW42 cells were incubated with D5W (blue coloration) or with PDS (green coloration) at $42{ }^{\circ} \mathrm{C}$ and slight shaking (30 rpm) for $30 \mathrm{~min}$ (a) or $60 \mathrm{~min}$ (b) and compared to untreated control cells cultured in medium (MEM; grey coloration). Histograms from flow cytometry showing cell counts versus forward scatter area (FSC-A) (left panels) and a comparison of FSC-A between the respective solvents (right panels). Significant differences are marked by an asterisk (*: $p<0.05$; Bonferroni corrected Student's $t$-test). Each data point represents the mean value of 3 replicates in independent experiments.

\section{Discussion}

Over the past decades, survival in metastatic CRC has widely improved. This is also true for metastases limited to the peritoneum, which were considered unresponsive to chemotherapy and therefore a generally palliative disease stage in the past [27]. Here CRS with HIPEC has relevantly enhanced patient prognosis. However, in CRC this complex compound treatment is currently highly controversial, since the randomized controlled PRODIGE 7 trial could not establish survival benefits for patients through adding OXbased HIPEC following CRS [13], whilst increasing morbidity and duration of hospital stay. 
Further, HIPEC using OX was unsuccessful in an another RCT in the adjuvant setting, where no benefit could be shown for HIPEC to decrease the incidence of metachronous peritoneal metastasis following primary CRC resection [28]. Certainly, it should not go unmentioned that CRS alone was able to increase median overall survival of patients to 41 months according to the PRODIGE 7 trial, which is unprecedented for this disease [13]. These unexpectedly high survival rates in both study cohorts have raised questions pertaining to the study design and the included patient population as well as to tumor biology. These issues include a high rate of crossovers into the HIPEC group and the inclusion of highly selected patients with heavy pretreatment (including systemic OX administration), therefore potentially weakening the validity of these trial results and limiting conclusions that can be drawn regarding HIPEC ineffectiveness $[29,30]$. In any case, HIPEC with OX currently faces pressure for justification.

Besides the prevailing controversies concerning the clinical use of HIPEC and the interpretation of the PRODIGE 7 trial results, including patient selection and speculations on acquired resistance of peritoneal metastases against OX [14-16,31], it should be acknowledged that preclinical research has never been a priority in the implementation of this treatment modality. The consequence of this is an abundance of different HIPEC protocols in clinical use [2,7] and lacking evidence regarding the precise mode of action of HIPEC. In accordance, taking a step back and systematically investigating the effects of the varying treatment parameters of HIPEC in a preclinical setting before implementation in clinical trials is a sensible strategy and should serve as an example [32]. One central but hitherto poorly answered question is the tissue penetration depth of drugs used for HIPEC and more importantly their respective biological effects on cells [17]. Low penetration depth has been identified early on as a potential limiting factor of intraperitoneal drug delivery [33], which was assumed to be a few millimeters at most [34]. While only sparse clinical data are available in this context and in spite of research that suggests an increased penetration depth with heat for OX [35], recent findings suggest ineffectiveness of $30 \mathrm{~min}$ OX-based HIPEC in organoids [21]. Therefore, to better assess tissue penetration depth during HIPEC and respective cytotoxic effects in a dedicated 2D model, we repurposed a RTCA assay [18], allowing the continuous assessment of a $\sim 100 \mu \mathrm{m}$ thick cell layer by using the platinum sensitive cell line OAW42 [20]. For our model we simulated HIPEC conditions by incubating cells with either peritoneal perfusate samples obtained during HIPEC treatment in patients or OX-containing solutions prepared at clinically relevant dosages by dilution in peritoneal dialysis or dextrose solutions $[7,13]$. Hence, we assume this model can elucidate the direct cytotoxic effects of HIPEC on peritoneal micrometastases. Moreover, it should be mentioned that OX cytotoxicity is well-established for the used cell lines, even at a fraction of the concentrations employed in our experiments [20,36].

The observed results underscore that short-term HIPEC with OX exerts only very slight effects in a model system that requires drugs to penetrate a distance of about 1/10 of a millimeter and to affect exposed cells in this way. A respective lack of effectiveness was witnessed in platinum-sensitive cells after 30 min HIPEC simulation with OX diluted in dextrose solutions over a wide concentration range, also encompassing the drug amounts employed in the PRODIGE 7 trial [13]. According to these results, OX only proved effective when diluted in peritoneal dialysis solution at the highest concentration tested and OX diluted in dextrose solution generally failed to decrease impedance values relevantly, thus suggesting a lack of a profound impact on residual metastatic tissue. Using sample materials obtained during HIPEC from 9 patients and characterized to contain a calculated mean of $93.7 \mu \mathrm{g} / \mathrm{mL}$ OX [18], no relevant effects were observed with materials from 6 patients following $30 \mathrm{~min}$ of HIPEC simulation within a measurement window of $72 \mathrm{~h}$. In contrast, prolonging exposure to $1 \mathrm{~h}$ relevantly improved cytotoxic effects and proved effective with materials from 7 patients. Further assessment of overall means from different patient samples emphasized lacking effectiveness of $30 \mathrm{~min}$ OX-based HIPEC in simulations as well as substantial improvements after prolongation to $60 \mathrm{~min}$, although with large variance underscoring relevant individual differences of the sample materials assessed. 
Recently a study in patient-derived CRC organoids likewise showed that prolonged exposure to $\mathrm{OX}$ at lower concentrations was more cytotoxic than short-term exposure at higher concentrations [37]. This notion generally conforms with our results, since the effects observed after simulated HIPEC with materials from 9 patients could be improved by prolonging simulated HIPEC treatment to $60 \mathrm{~min}$. Regarding the RTCA assay with OX-containing solutions prepared at clinically relevant dosages, unfortunately we cannot conclude comprehensively on HIPEC prolongation to $1 \mathrm{~h}$, since with dextrose solution our model proved unsuitable due to cell detachment. Nevertheless, the results from short-term exposure were supported by the assessment of 2 different cell lines in 2 well-established endpoint assays using a comparable setting: following $30 \mathrm{~min}$ of OX-based HIPEC simulation, less than $25 \%$ reduction of cell viability was observed compared to values below $50 \%$ cell viability when continuously exposed to OX even at low concentrations. Likewise, long term exposure to OX even at relatively low concentrations unanimously eliminated the exposed cell layer in our RTCA model.

Evidently, as HIPEC involves a variety of factors, these may become relevant in the context of different drugs used and influence molecular mechanisms relevant for anticancer effects. Importantly, both the exposure period and heat have been implicated in HIPEC effects. For instance, in vitro studies with OX have shown increased drug uptake and DNA damage with heat, resulting in increased apoptosis but still required $60 \mathrm{~min}$ exposure for effectiveness in respective CRC models, whereas, e.g., mitomycin C lacked such synergistic effects [38]. Further, it is known that heat inhibits DNA repair, e.g., through inhibiting poly(ADP-ribose)-polymerase (PARP1), and therefore it can sensitize cells for chemotherapy $[39,40]$. Another important determinant in HIPEC is the solvent used to dilute the drugs. Here we observed significant cell size reduction of about $25 \%$ after $30 \mathrm{~min}$, persisting also at $60 \mathrm{~min}$ under hyperthermic conditions with both tested solvents (PDS and D5W as compared to medium). We speculate that the observed changes are most likely caused by a fluid shift to the extracellular space, which also occurs during HIPEC treatment and may impair drug penetration into tissues.

As a limitation of this modelling study it should be acknowledged that this system is artificial, since merely effects on platinum-sensitive cancer cells are assessed and the peritoneal microenvironment cannot be imitated. In reality, increased interstitial fluid pressure in the tumor [41], tissue cohesion, edema formation, and other factors may likely complicate the picture. Using sample materials obtained during HIPEC from patients also has immanent limitations, since, e.g., we found previously that the administered OX does react with contents of peritoneal dialysis solutions by forming new compounds [18], which may affect cellular uptake and molecular drug mechanisms.

Apart from this, the introduced model has several advantages compared to alternative approaches. These include the possibility to investigate HIPEC effects continuously in the 2D model under specific consideration of the penetration depth, which is in contrast to 3D models that show considerably higher degrees of freedom, e.g., with regard to organoid size and other properties [21,37]. Due to the biosensors' functional assessment a spatial resolution is ensured, informing only about the cell viability of those cells located at the well bottom. Thereby effects on cells can be directly investigated, avoiding the extrapolation of biological effects from drug penetration depth, which itself comes with immanent limitations and idiosyncrasies [42]. Our assay is robust and shows consistency and good reproducibility, allowing for systematic comparisons to be performed. Further continuous measurements provide a good temporal resolution and are therefore more sensitive to changes occurring with delay and superior to end-point assays. Hitherto, there are few good preclinical models for laboratory use and our model is unique in several aspects, adding a new tool to HIPEC research.

Overall, preclinical models for HIPEC are scarce and mainly restricted to animal models so far $[43,44]$, whereas adequate model systems have only been established very recently $[21,32,37]$. If the findings observed for OX hold true for other tumor entities and 
drugs used for HIPEC and under normothermic conditions remains unclear, which is why our model system may be a worthwhile addition for future research.

\section{Conclusions}

Overall, our investigations showed severely limited effects of short-term OX-based HIPEC, in line with previous research. We now show that the desired effects could be improved by prolonged exposure. Strikingly, our simulations of HIPEC treatment in platinum-sensitive cell lines using excessive OX dosages proved insufficient to eradicate even minimal tumor cell accumulations.

Thus, the presented work may support the notion that short-term OX-based HIPEC is ineffective to eliminate peritoneal micrometastasis and may hint to possible causes for this failure. Our findings suggest that drug distribution into deeper tissue layers may be a crucial factor as well as exposure time but also the solvents used for OX dilution in HIPEC may substantially alter drug induced effects.

Based on the restricted penetration depth of most HIPEC drugs [45], systematic preclinical research is warranted. Taken together, HIPEC - in contrast to CRS-remains an experimental approach for treatment of peritoneal metastasis originating from CRC and new evidence is urgently needed.

Supplementary Materials: The following are available online at https:/ /www.mdpi.com/article/10 .3390/cancers14051158/s1, Figure S1: Assessment of the thickness of an OAW42 cell layer seeded at different densities; Figure S2: RTCA: Pat. 2: Exposure of OAW42 cells to OCS for 30 min at $42{ }^{\circ} \mathrm{C}$; Figure S3: RTCA: Pat. 2: Exposure of OAW42 cells to OCS for 60 min at $42{ }^{\circ} \mathrm{C}$; Figure S4: RTCA: Pat. 4: Exposure of OAW42 cells to OCS for $30 \mathrm{~min}$ at $42{ }^{\circ} \mathrm{C}$; Figure S5: RTCA: Pat. 4: Exposure of OAW42 cells to OCS for $60 \mathrm{~min}$ at $42{ }^{\circ} \mathrm{C}$; Figure S6: RTCA: Pat. 5: Exposure of OAW42 cells to OCS for $30 \mathrm{~min}$ at $42{ }^{\circ} \mathrm{C}$; Figure S7: RTCA: Pat. 5: Exposure of OAW42 cells to OCS for $60 \mathrm{~min}$ at $42{ }^{\circ} \mathrm{C}$; Figure S8: RTCA: Pat. 6: Exposure of OAW42 cells to OCS for 30 min at $42{ }^{\circ} \mathrm{C}$; Figure S9: RTCA: Pat. 6: Exposure of OAW42 cells to OCS for $60 \mathrm{~min}$ at $42^{\circ} \mathrm{C}$; Figure S10: RTCA: Pat. 7: Exposure of OAW42 cells to OCS for $30 \mathrm{~min}$ at $42^{\circ} \mathrm{C}$; Figure S11: RTCA: Pat. 7: Exposure of OAW42 cells to OCS for $60 \mathrm{~min}$ at $42{ }^{\circ} \mathrm{C}$; Figure S12: RTCA: Pat. 8: Exposure of OAW42 cells to OCS for $30 \mathrm{~min}$ at $42{ }^{\circ} \mathrm{C}$; Figure S13: RTCA: Pat. 8: Exposure of OAW42 cells to OCS for $60 \mathrm{~min}$ at $42^{\circ} \mathrm{C}$; Figure S14: RTCA: Pat. 9: Exposure of OAW42 cells to OCS for $30 \mathrm{~min}$ at $42^{\circ} \mathrm{C}$; Figure S15: RTCA: Pat. 9: Exposure of OAW42 cells to OCS for $60 \mathrm{~min}$ at $42^{\circ} \mathrm{C}$; Figure S16: RTCA: Oxaliplatin (OX)-spiked into PDS $60 \mathrm{~min}$ at $42{ }^{\circ} \mathrm{C}$; Figure S17: RTCA: Continuous exposure of OAW42 cells to OCS in PDS; Figure S18: RTCA: Continuous exposure of OAW42 cells to OCS in D5W.

Author Contributions: Conceptualization: T.J., S.V., S.B. and M.W.L. Data curation: N.S., M.B. Formal analysis: N.S., M.B., A.T., F.H., J.K., S.V. and M.W.L. Investigation: N.S., M.B., B.O., F.H., J.K. and M.W.L. Methodology: N.S., M.B., S.B. and M.W.L. Validation: N.S., C.Y., M.B., B.O., J.K., M.Q. and M.W.L. Visualization: N.S., C.Y., M.B., and M.W.L. Project administration: C.Y., A.T., T.J., K.T., S.V. and M.W.L. Funding acquisition: I.K., A.K. and M.W.L. Resources: I.K., K.T., H.-G.R., M.S. and A.K. Supervision: C.Y., A.T., K.T., H.-G.R., S.V., M.S., A.K. and S.B. Writing-original draft: N.S., C.Y. and M.W.L. Writing—review and editing: M.B., B.O., A.T., F.H., J.K., T.J., I.K., K.T., M.Q., H.-G.R., S.V., M.S., A.K. and S.B. All authors have read and agreed to the published version of the manuscript.

Funding: We acknowledge support by Open Access Publishing Fund of University of Tübingen. This work was supported by the Robert Bosch Stiftung (Stuttgart, Germany), and the Deutsche Forschungsgemeinschaft (DFG, German Research Foundation) under Germany's Excellence Strategy-EXC 2180-390900677. This work was supported by grants from the Deutsche Forschungsgemeinschaft (DFG, SFB 685) to I. Königsrainer and A. Königsrainer. The funders had no role in the design of the study, in the collection, analyses, or interpretation of data, in the writing of the manuscript, or in the decision to publish the results.

Institutional Review Board Statement: The study was conducted according to the guidelines of the Declaration of Helsinki, and approved by the Institutional Review Board of the Medical Faculty at the University of Tübingen and of the University Hospital (project number: 367/2013BO1).

Informed Consent Statement: Informed consent was obtained from all patients involved in the study. 
Data Availability Statement: The data presented in this study is contained within the article or Supplementary Materials further information is available on request from the corresponding author.

Acknowledgments: The authors would like to thank Jan Franko, Des Moines, Iowa for insights, encouragement, and helpful discussions. We also thank Jürgen Winter, Department of General, Visceral and Transplant Surgery, University Hospital of Tübingen, for excellent technical support as well as Jürgen Weinreich, and Philipp Horvath, for support with obtaining sample materials. The authors would like to acknowledge the contributions of Sebastian P. Haen, University Medical Center Hamburg-Eppendorf, to this study and we would like to commemorate him and his scientific excellence, exceptional personality and friendship.

Conflicts of Interest: S. Venturelli and M. Burkard were supported by a grant from the ElseÜbelmesser-Stiftung (D.30.21947; reference: GzV 1.14) of the University of Tübingen unrelated to the present work. M. W. Löffler and A. Königsrainer have received a research grant by RanD S.r.l., a manufacturer of devices and consumables for HIPEC, unrelated to the present work. The other authors declare no potential conflict of interest.

\section{References}

1. Verwaal, V.J.; Van Ruth, S.; De Bree, E.; Van Slooten, G.W.; Van Tinteren, H.; Boot, H.; Zoetmulder, F.A. Randomized Trial of Cytoreduction and Hyperthermic Intraperitoneal Chemotherapy Versus Systemic Chemotherapy and Palliative Surgery in Patients With Peritoneal Carcinomatosis of Colorectal Cancer. J. Clin. Oncol. 2003, 21, 3737-3743. [CrossRef] [PubMed]

2. Helderman, R.F.C.P.A.; Löke, D.R.; Kok, H.P.; Oei, A.L.; Tanis, P.J.; Franken, N.A.P.K.; Crezee, J. Variation in Clinical Application of Hyperthermic Intraperitoneal Chemotherapy: A Review. Cancers 2019, 11, 78. [CrossRef] [PubMed]

3. Jacquet, P.; Sugarbaker, P.H. Peritoneal-plasma barrier. Cancer Treat. Res. 1996, 82, 53-63. [CrossRef] [PubMed]

4. Kusamura, S.; Barretta, F.; Yonemura, Y.; Sugarbaker, P.H.; Moran, B.J.; Levine, E.A.; Goere, D.; Baratti, D.; Nizri, E.; Morris, D.L.; et al. The Role of Hyperthermic Intraperitoneal Chemotherapy in Pseudomyxoma Peritonei After Cytoreductive Surgery. JAMA Surg. 2021, 156, e206363. [CrossRef]

5. Lin, Y.-L.; Xu, D.-Z.; Li, X.-B.; Yan, F.-C.; Xu, H.-B.; Peng, Z.; Li, Y. Consensuses and controversies on pseudomyxoma peritonei: A review of the published consensus statements and guidelines. Orphanet J. Rare Dis. 2021, 16, 85. [CrossRef]

6. Van Driel, W.J.; Koole, S.N.; Sikorska, K.; Van Leeuwen, J.H.S.; Schreuder, H.W.R.; Hermans, R.H.M.; De Hingh, I.H.J.T.; Van Der Velden, J.; Arts, H.J.; Massuger, L.F.A.G.; et al. Hyperthermic Intraperitoneal Chemotherapy in Ovarian Cancer. N. Engl. J. Med. 2018, 378, 230-240. [CrossRef]

7. Yurttas, C.; Hoffmann, G.; Tolios, A.; Haen, S.P.; Schwab, M.; Königsrainer, I.; Königsrainer, A.; Beckert, S.; Löffler, M.W.; Yurttas, C.; et al. Systematic Review of Variations in Hyperthermic Intraperitoneal Chemotherapy (HIPEC) for Peritoneal Metastasis from Colorectal Cancer. J. Clin. Med. 2018, 7, 567. [CrossRef]

8. $\quad$ Elias, D.; Bonnay, M.; Puizillou, J.M.; Antoun, S.; Demirdjian, S.; El Otmany, A.; Pignon, J.-P.; Drouard-Troalen, L.; Ouellet, J.F.; Ducreux, M. Heated intra-operative intraperitoneal oxaliplatin after complete resection of peritoneal carcinomatosis: Pharmacokinetics and tissue distribution. Ann. Oncol. 2002, 13, 267-272. [CrossRef] [PubMed]

9. Mehta, S.S.; Bhatt, A.; Glehen, O. Cytoreductive Surgery and Peritonectomy Procedures. Indian J. Surg. Oncol. 2016, 7, 139-151. [CrossRef]

10. Kuijpers, A.; Hauptmann, M.; Aalbers, A.; Nienhuijs, S.; de Hingh, I.; Wiezer, M.; van Ramshorst, B.; van Ginkel, R.; Havenga, K.; Verwaal, V. Cytoreduction and hyperthermic intraperitoneal chemotherapy: The learning curve reassessed. Eur. J. Surg. Oncol. (EJSO) 2016, 42, 244-250. [CrossRef]

11. Moradi, B.N.; Esquivel, J. Learning curve in cytoreductive surgery and hyperthermic intraperitoneal chemotherapy. J. Surg. Oncol. 2009, 100, 293-296. [CrossRef] [PubMed]

12. Morales-Soriano, R.; Esteve-Pérez, N.; Segura-Sampedro, J.J.; Cascales-Campos, P.; Barrios, P.; Alonso-Gómez, J.; García-Fadrique, A.; Arjona-Sánchez, A.; Arteaga-Martín, X.; Bretcha-Boix, P.; et al. Current practice in cytoreductive surgery and HIPEC for metastatic peritoneal disease: Spanish multicentric survey. Eur. J. Surg. Oncol. (EJSO) 2018, 44, 228-236. [CrossRef] [PubMed]

13. Quénet, F.; Elias, D.; Roca, L.; Goéré, D.; Ghouti, L.; Pocard, M.; Facy, O.; Arvieux, C.; Lorimier, G.; Pezet, D.; et al. Cytoreductive surgery plus hyperthermic intraperitoneal chemotherapy versus cytoreductive surgery alone for colorectal peritoneal metastases (PRODIGE 7): A multicentre, randomised, open-label, phase 3 trial. Lancet Oncol. 2021, 22, 256-266. [CrossRef]

14. Ceelen, W. HIPEC with oxaliplatin for colorectal peritoneal metastasis: The end of the road? Eur. J. Surg. Oncol. (EJSO) 2018, 45, 400-402. [CrossRef]

15. Königsrainer, A.; Rau, B. Cytoreductive Surgery (CRS) and Hyperthermic IntraPeritoneal Chemotherapy (HIPEC): Don't throw the baby out with the bathwater. Pleura Peritoneum 2018, 3, 20180131. [CrossRef]

16. Yurttas, C.; Fisher, O.M.; Cortés-Guiral, D.; Haen, S.P.; Königsrainer, I.; Königsrainer, A.; Beckert, S.; Liauw, W.; Löffler, M.W. Cytoreductive surgery and HIPEC in colorectal cancer-did we get hold of the wrong end of the stick? Mag. Eur. Med Oncol. 2020, 13, 434-439. [CrossRef]

17. Ceelen, W.; Demuytere, J.; de Hingh, I. Hyperthermic Intraperitoneal Chemotherapy: A Critical Review. Cancers 2021, 13, 3114. [CrossRef] 
18. Löffler, M.W.; Schuster, H.; Zeck, A.; Quilitz, N.; Weinreich, J.; Tolios, A.; Haen, S.P.; Horvath, P.; Löb, S.; Rammensee, H.-G.; et al. Pharmacodynamics of Oxaliplatin-Derived Platinum Compounds During Hyperthermic Intraperitoneal Chemotherapy (HIPEC): An Emerging Aspect Supporting the Rational Design of Treatment Protocols. Ann. Surg. Oncol. 2017, 24, 1650-1657. [CrossRef]

19. Limame, R.; Wouters, A.; Pauwels, B.; Fransen, E.; Peeters, M.; Lardon, F.; De Wever, O.; Pauwels, P. Comparative Analysis of Dynamic Cell Viability, Migration and Invasion Assessments by Novel Real-Time Technology and Classic Endpoint Assays. PLoS ONE 2012, 7, e46536. [CrossRef]

20. Roberts, D.; Schick, J.; Conway, S.; Biade, S.; Laub, P.B.; Stevenson, J.P.; Hamilton, T.C.; O’Dwyer, P.J.; Johnson, S.W. Identification of genes associated with platinum drug sensitivity and resistance in human ovarian cancer cells. Br. J. Cancer 2005, 92, 1149-1158. [CrossRef]

21. Ubink, I.; Bolhaqueiro, A.C.F.; Elias, S.G.; Raats, D.A.E.; Constantinides, A.; Peters, N.A.; Wassenaar, E.C.E.; De Hingh, I.H.J.T.; Rovers, K.P.; Van Grevenstein, W.M.U.; et al. Organoids from colorectal peritoneal metastases as a platform for improving hyperthermic intraperitoneal chemotherapy. Br. J. Surg. 2019, 106, 1404-1414. [CrossRef] [PubMed]

22. O'Brien, J.; Wilson, I.; Orton, T.; Pognan, F. Investigation of the Alamar Blue (resazurin) fluorescent dye for the assessment of mammalian cell cytotoxicity. Eur. J. Biochem. 2000, 267, 5421-5426. [CrossRef] [PubMed]

23. Orellana, E.A.; Kasinski, A.L. Sulforhodamine B (SRB) Assay in Cell Culture to Investigate Cell Proliferation. Bio. Protocol. 2016, 6, e1984. [CrossRef] [PubMed]

24. Martinez-Maqueda, D.; Miralles, B.; Recio, I. HT29 Cell Line. In The Impact of Food Bioactives on Health: In Vitro and Ex Vivo Models; Verhoeckx, K., Cotter, P., Lopez-Exposito, I., Kleiveland, C., Lea, T., Mackie, A., Requena, T., Swiatecka, D., Wichers, H., Eds.; Springer: Cham, Switzerland; Heidelberg, Germany; New York, NY, USA; Dordrecht, The Netherlands; London, UK, 2015; pp. 113-124. ISBN 978-3-319-16104-4. [CrossRef]

25. Shoemaker, R.H. The NCI60 human tumour cell line anticancer drug screen. Nat. Cancer 2006, 6, 813-823. [CrossRef] [PubMed]

26. Kim, M.K.; Osada, T.; Barry, W.T.; Yang, X.Y.; Freedman, J.A.; Tsamis, K.A.; Datto, M.; Clary, B.M.; Clay, T.; Morse, M.A.; et al. Characterization of an Oxaliplatin Sensitivity Predictor in a Preclinical Murine Model of Colorectal Cancer. Mol. Cancer Ther. 2012, 11, 1500-1509. [CrossRef]

27. Lambert, L.A. Looking up: Recent advances in understanding and treating peritoneal carcinomatosis. CA: A Cancer J. Clin. 2015, 65, 283-298. [CrossRef]

28. Klaver, C.E.L.; Wisselink, D.D.; Punt, C.J.A.; Snaebjornsson, P.; Crezee, J.; Aalbers, A.G.J.; Brandt, A.; Bremers, A.J.A.; Burger, J.W.A.; Fabry, H.F.J.; et al. Adjuvant hyperthermic intraperitoneal chemotherapy in patients with locally advanced colon cancer (COLOPEC): A multicentre, open-label, randomised trial. Lancet Gastroenterol. Hepatol. 2019, 4, 761-770. [CrossRef]

29. Cashin, P.; Sugarbaker, P.H. Hyperthermic intraperitoneal chemotherapy (HIPEC) for colorectal and appendiceal peritoneal metastases: Lessons learned from PRODIGE 7. J. Gastrointest. Oncol. 2021, 12, S120-S128. [CrossRef]

30. Rovers, K.P.; Kok, N.F.M.; Punt, C.J.A.; Tanis, P.J.; de Hingh, I.H.J.T. Limitations of the PRODIGE 7 trial. Lancet Oncol. 2021, 22, e174. [CrossRef]

31. Nagourney, R.A.; Evans, S.; Tran, P.H.; Nagourney, A.J.; Sugarbaker, P.H. Colorectal cancer cells from patients treated with FOLFOX or CAPOX are resistant to oxaliplatin. Eur. J. Surg. Oncol. (EJSO) 2020, 47, 738-742. [CrossRef]

32. Helderman, R.; Löke, D.; Tanis, P.; Tuynman, J.; Ceelen, W.; de Hingh, I.; van der Speeten, K.; Franken, N.; Oei, A.; Kok, H.; et al. Preclinical In Vivo-Models to Investigate HIPEC; Current Methodologies and Challenges. Cancers 2021, 13, 3430. [CrossRef] [PubMed]

33. Dedrick, R.L. Theoretical and experimental bases of intraperitoneal chemotherapy. Semin. Oncol. 1985, 12, 1-6. [PubMed]

34. Butcher, D.T.; Alliston, T.; Weaver, V.M. A tense situation: Forcing tumour progression. Nat. Cancer 2009, 9, 108-122. [CrossRef]

35. Pestieau, S.R.; Belliveau, J.F.; Griffin, H.; Stuart, O.A.; Sugarbaker, P.H. Pharmacokinetics of intraperitoneal oxaliplatin: Experimental studies. J. Surg. Oncol. 2001, 76, 106-114. [CrossRef]

36. Mehta, A.; Hoven, J.V.D.; Rosing, H.; Hillebrand, M.; Nuijen, B.; Huitema, A.; Beijnen, J.; Verwaal, V. Stability of oxaliplatin in chloride-containing carrier solutions used in hyperthermic intraperitoneal chemotherapy. Int. J. Pharm. 2015, 479, 23-27. [CrossRef]

37. Forsythe, S.D.; Sasikumar, S.; Moaven, O.; Sivakumar, H.; Shen, P.; Levine, E.A.; Soker, S.; Skardal, A.; Votanopoulos, K.I. Personalized Identification of Optimal HIPEC Perfusion Protocol in Patient-Derived Tumor Organoid Platform. Ann. Surg. Oncol. 2020, 27, 4950-4960. [CrossRef]

38. Helderman, R.F.; Löke, D.R.; Verhoeff, J.; Rodermond, H.M.; Van Bochove, G.G.; Boon, M.; Van Kesteren, S.; Vallejo, J.J.G.; Kok, H.P.; Tanis, P.J.; et al. The Temperature-Dependent Effectiveness of Platinum-Based Drugs Mitomycin-C and 5-FU during Hyperthermic Intraperitoneal Chemotherapy (HIPEC) in Colorectal Cancer Cell Lines. Cells 2020, 9, 1775. [CrossRef]

39. Oei, A.L.; Vriend, L.E.M.; Crezee, J.; Franken, N.A.P.; Krawczyk, P.M. Effects of hyperthermia on DNA repair pathways: One treatment to inhibit them all. Radiat. Oncol. 2015, 10, 165. [CrossRef]

40. Schaaf, L.; Schwab, M.; Ulmer, C.; Heine, S.; Mürdter, T.E.; Schmid, J.O.; Sauer, G.; Aulitzky, W.E.; Van Der Kuip, H. Hyperthermia Synergizes with Chemotherapy by Inhibiting PARP1-Dependent DNA Replication Arrest. Cancer Res. 2016, 76, $2868-2875$. [CrossRef]

41. Less, J.R.; Posner, M.C.; Boucher, Y.; Borochovitz, D.; Wolmark, N.; Jain, R.K. Interstitial hypertension in human breast and colorectal tumors. Cancer Res. 1992, 52, 6371-6374. 
42. Larroque, M.; Mounicou, S.; Sgarbura, O.; Arnaudguilhem, C.; Rebel, L.; Leaha, C.; Faye, P.-A.; Enjalbal, C.; Quénet, F.; Bouyssiere, B.; et al. Study of oxaliplatin penetration into ovaries of patients treated with hyperthermic intraperitoneal chemotherapy (HIPEC) for peritoneal metastases of colorectal and appendiceal origin using mass spectrometry imaging. Pleura Peritoneum 2021, 6, 67-74. [CrossRef] [PubMed]

43. Gremonprez, F.; Willaert, W.; Ceelen, W. Intraperitoneal chemotherapy (IPC) for peritoneal carcinomatosis: Review of animal models. J. Surg. Oncol. 2014, 109, 110-116. [CrossRef]

44. Gremonprez, F.; Willaert, W.; Ceelen, W. Animal models of colorectal peritoneal metastasis. Pleura Peritoneum 2016, 1, 23-43. [CrossRef] [PubMed]

45. Ceelen, W.P.; Pahlman, L.; Mahteme, H. Pharmacodynamic aspects of intraperitoneal cytotoxic therapy. Cancer Treat. Res. 2007, 134, 195-214. [CrossRef] [PubMed] 